\title{
淀川におけるイタセンパラ生息水域の 水理学的特性 \\ HYDRAULIC PROPERTY OF THE HABITAT OF ACHEILOGNATHUS LONGIPINNIS IN THE LOWER REACH OF THE YODO RIVER
}

\author{
野地 貴弘 1 ・綾 史郎 2 ・馬場 葵 3 \\ Takahiro NOJI, Shirou AYA, Aoi BABA \\ 1学生員 大阪工業大学大学院 工学研究科都市デザイン工学専攻（† 535-8585 大阪市旭区大宮5-16-1） \\ 2 正会員 博 (工） 大阪工業大学工学部 都市デザイン工学科（†535-8585 大阪市旭区大宮5-16-1) \\ 3非会員＼cjkstart株式会社イシキ（†631-0541 奈良市石木町160-1）
}

\begin{abstract}
This paper deals with the hydraulic and hydrologic properties of the habitat of fish in a river and surrounding area. It especially focuses on the habitat of the Acheilognathus Longipinnis in the lower reach of the Yodo River, because the restoration of its habitat is the most important and urgent work for the Yodo River eco-system. The estimation of flood disturbance required for the life history of the fish was examined in the Akagawa sand bar and Shirokita Embayments, where both areas were its most important habitat 40 years ago, through the return period of the magnitude of the flood discharge, the frequency of the water surface elevation, which were obtained by the statistics of the water surface elevation records, and the magnitude of the order of the velocity and the shear velocity and their distributions, which were obtained through the 2-D numerical simulation. The results will be usable for the selection of the location of the newly constructed habitat, and its design.
\end{abstract}

Key Words : fish habitat, embayment, temporary water area, flood disturbances, river eco-system

\section{1. はじめに}

ワンドは河川本流に隣接した浅い水域であり，複雑 な形状の河岸を構成するとともに，流水性及び止水性 の双方の性格を有し，多様な魚貝類の生息場として知 られているが゙，近年，河川における魚貝類の生息場と しては平水時には本川と分離しているが, 出水時には 冠水によって本川と連結する恒久的水域であるタマリ や，出水時には水域として存在するが水位の低下とと もにやがて消滅する一時的水域の重要性も指摘されて (る2).

15個を超えるワンドからなる城北ワンド群をはじめ と寸る淀川本川下流は1970年代から2000年代にかけて 天然記念物であるイタセンパラやアユモドキなどの貴 重種を含む，淡水魚貝類の宝庫であったが，2010年現 在，イタセンパラをはじめとする多くの魚種の未確認 状態が続いており，淀川本川下流水域の環境は変質・ 劣化してしまった. その主因としては河川改修による 地形や流れの変化, およびそれにともなう外来種の急 激な増加などが言われている3)。1970年代当時, 城北ワ ンド群が存在する淀川本川下流の河口から11.0〜
13. $0 \mathrm{~km}$ 付近には淀川本流, 城北ワンド群に加えて, 赤 川ワンド・タマリ群, 豊里タマリ群などの冒頭に述べ たような多様な水域が密集し, 多様な水生生物の生息 場を構成していたものと推定され，淀川本川下流水域 の生態系の復元に当たっては城北ワンド群の保全やワ ンドの復元・創造だけでは不十分であって, 多様な水 域と流れのシステムの再構築が必要と筆者らは考えて いる. 本研究は, このような見地から1970年代にイタ センパラの主要な生息水域であった城北ワンド群およ びその下流に隣接する赤川ワンド・タマリ群の洪水時 の擋乱を中心とした水理環境を明らかにしようとする ものである. 1970年代からの河川改修により赤川ワン ド・タマリ群はその水域がほとんど失われ, 城北ワンド 群は保全されたが，ともに水文・水理環境の変化が著 しい. 以下の研究では, 1970年代の地形, 水位や流量 などの水文状況を用いた数值シミュレーションにより 赤川地区の本流，ワンド・タマリ群の洪水時の流れや 摩擦速度などのイタセンパラの生息水域の水理学的環 境を明らかにする.さらに, 現在も水域としては残さ れているが, 変化の著しい城北ワンド群周辺の水理環 境の変化の推定も行い, 淀川生態系の物理的環境の復 元に役立てようとするものである. 


\section{2. 赤川砂州のワンド・タマリ群と城北ワンド群}

赤川地区は，淀川本川の河口から約 $11.0 \mathrm{~km}$ 上流左岸 に位置し, 直下流に淀川大堰 $(9.8 \mathrm{~km})$ が, また, 直上 流には城北ワンド群（11. 5km〜13.5km）がある. 1897 （明治30）年に始まった淀川改良工事の前後の河道地 形が分かる図-1に示されるように，この明治の大改修 以前, 現在の鳥飼大橋付近 $(17.2 \mathrm{~km})$ から淀川大堰付 近にかけては蛇行が著しく, 淀川改良工事により現在 の八雲地区 $(15.0 \mathrm{~km} \sim 16.0 \mathrm{~km})$ では堤防を東側に, 毛 馬・赤川地区（10.0km〜12. $0 \mathrm{~km} ）$ では堤防を南側に設 け，出水時の川幅を広げるとともに，城北地区では河 道を北側に移設し, 蛇行を緩和した. その後, 水制工 が再整備された。同図には築堤用の土砂採取跡の四角 形や水路状の水たまりが散見される. その後, 1960年 頃までに再三，整備・補修された水制工上に砂がたま り，砂州が形成されるとともに，多くのワンドやタマ リが出来たことと, 澪筋（低水路）が大きく蛇行して いることが知られている1).

イタセンパラは1960年代の一時淀川水系では確認さ れなかったが，1969年大阪府立市岡高校生物部により 赤川砂州の赤川鉄橋橋脚直下の本川沿いのワンドで再 発見された. 当時の地形を1972年測量の平面図で図-2 に示した. 図-2には多くのワンドやタマリが描かれて いるが，水管橋（10.9km） と赤川鉄橋（11.3km）間の 砂州の主要部には大小16個のワンド・タマリ群が判別で きる.これらのタマリの多くでイタセンパラが生息し ていたことが当時の調査 ${ }^{4}$ ５) で確認されている. 赤川ワ ンド・タマリ群のほとんどは常時は本川と隔離され, 出水時にのみ連結する浅い恒久的水域であり, 赤川夕 マリ群が破壊される1989年まで，イタセンパラの生息 が確認されていたことが重要である. 赤川砂州には平 水位よりやや高い場所に存在する恒久的水域である夕 マリや, 出水時には水域として存在するが水位の低下 とともにやがて消滅する一時的水域も存在した。一方， 城北ワンド群は恒久的な水域であり, 平水時から本川

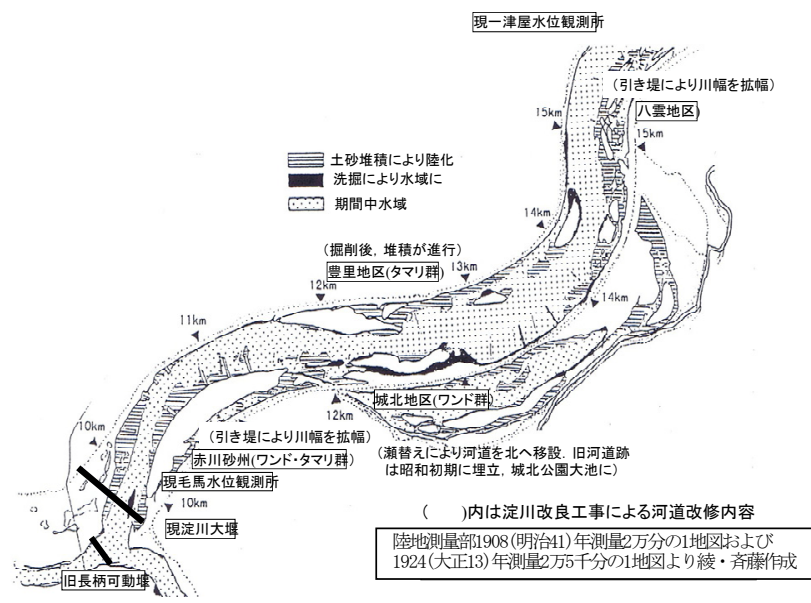

図-1 1908年から1924年頃までの淀川下流の河道変形1．
と連結する浅い水域を提供した.

\section{3. 赤川ワンド - タマリ群周辺の地形と冠水状況}

図-3は1975（昭和50）年測量の赤川砂州周辺の11.0, 11.2，11.4，11.6kmの各横断図を重ね合わせたもので ある. 同様に図-4は1971年測量の $200 \mathrm{~m}$ 毎の横断図から 地盤標高の等高線を描いたものである。これらの図か ら分かるように, 赤川地区では対岸の右岸堤防際まで 澪筋が寄り, 平水時の水路幅は150〜250m程度となって いる. よく知られるように湾曲部の外岸側は洗掘され やすく, 1975年当時の最深河床の標高はOP-7. Omであり， 平水位 $0 \mathrm{P}+2.5 \mathrm{~m}$ の時の水深は $9.5 \mathrm{~m}$ と深い淵を形成してい る. 砂州上には前述のように16個のワンド・タマリ群 が確認されるが，水深が $1 \mathrm{~m}$ 程度以下の浅い部分は本流 沿いには少なく, 上流部分の断面 $11.4 \mathrm{~km}, 11.6 \mathrm{~km}$ の本 川左河岸沿い，44号，42号ワンド，および左岸側上流 に続く城北ワンド群に広がっていることがわかる.

図-5は城北，赤川地区の下流に位置する長柄（毛 馬）量水標（10.2km） と上流に位置する一津屋量水標 （16. $0 \mathrm{~km})$ の日平均水位を用いて得られる特性水位 (位況図より得られる年最高，8，22，71，95，185， $275 ， 355$ 番目，年最低の水位） ${ }^{6}$ およびそれらから内挿 された赤川（11.2km）特性水位について, 淀川大堰が 改築される以前の1972～1979年（長柄），1971～1976 年 (一津屋) の平均値を示したものである. 図-4及び 図-5を用いて標高 $0 \mathrm{P}+2.5 \mathrm{~m} \sim 3.0 \mathrm{~m}$ 年間冠水日数を調心 ると，毛馬地区で36〜354日，赤川地区で71〜365日， 一津屋地区で95 365日冠水する地帯に相当し, 城北ワ ンド群の一部と対岸の豊里タマリ群の大部分がこの領 域に入っている. また, 赤川砂州は標高 $0 \mathrm{P}+3.0 \sim 3.5 \mathrm{~m}$ に広がっていることから，赤川地区の特性水位より 22 〜 70日冠水する地帯が赤川砂州一帯に広がっているこ とが分かる. 赤川砂州は湾曲部の内岸にできる固定砂 州であるが，前掲の横断図（図-3）に見られるように， 下流側の $11.0 \mathrm{~km}, 11.2 \mathrm{~km}$ 砂州先端部は標高 $0 \mathrm{P}+5 \mathrm{~m}$ と高

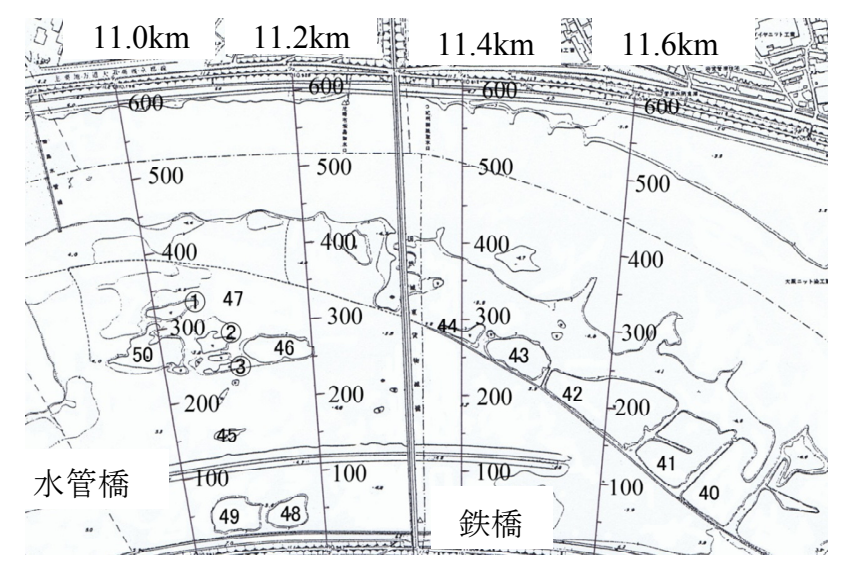

図-2 1972 (昭和47) 年の赤川砂州とワンド・タマリ群. 
く，上流側の $11.4 \mathrm{~km} ， 11.6 \mathrm{~km}$ の砂州先端部は $3.5 \mathrm{~m}$ 程度 と低い，砂州の主要部である $11.0 \mathrm{~km}, 11.2 \mathrm{~km}, 11.4 \mathrm{~km}$ の横断測量線沿いには大小の凹凸が見られ，本川とは 分離した恒久的な水域であることが分かる。これらの タマリの冠水頻度についてみると, 赤川地区の71日水 位が先述のように $\mathrm{P}+2.98 \mathrm{~m}, 22$ 日水位が $\mathrm{P}+3.41 \mathrm{~m}$ と推 察されるので図-5からは標高0P+3.0mの序列を70日， 4. $5 \mathrm{~m}$ の序列を 5 日と推定できるので，冠水日数を 5 〜 70 日程度と推定できる。

1972年から2008年までの毛馬（長柄）水位観測所の 日平均水位記録から作成された年最大，平水（85日） 年最小等の特性水位の経年変化を図-6に示した。同図 より淀川大堰が運用を開始した1983（昭和58）年を境 として，1）それ以前には洪水時には3mを越える水位上 昇が生じていたが，1983年以降，0.5m程度の水位上昇 しか生じず，淀川下流の水位の周年変化が全く異なっ ていること，2）平水位が $0.5 \mathrm{~m}$ 程度上昇していることが 知られる. 図-5にも見られる様に，赤川地区の1970年 代の年最高水位は5.0mを越えており, 砂州全体が年1回 程度は冠水していたことが知れる．砂州の標高を $3.5 \mathrm{~m}$, 最大水深を $1.5 \mathrm{~m}$ ，エネルギー勾配を $1 / 5000$ 程度と仮定 すると，摩擦速度は $\mathrm{u}_{*}=0.054 \mathrm{~m} / \mathrm{s}$ となる．岩垣式により 移動可能最大砂粒子径を概算すると，砂州上では $0.3 \mathrm{~cm}$ 程度の砂礫が移動していると推察された.

一方，1984年以降，年最大水位がOP+3. 5mを超えるこ とは希であり，1）赤川砂州が冠水することはほとんど なくなり，改修工事により砂州主要部の恒久的なタマ

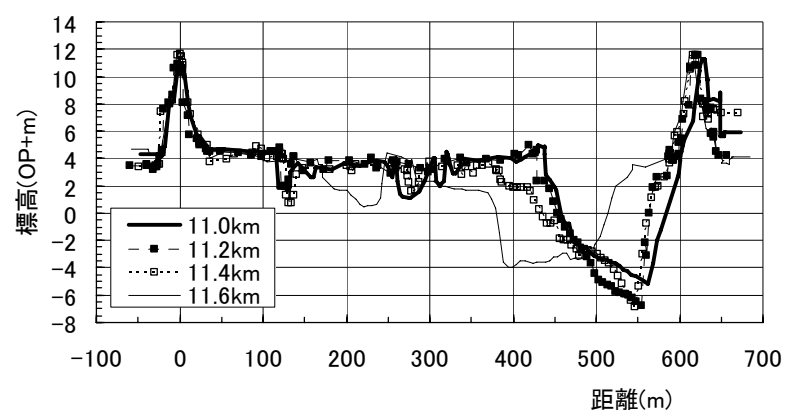

図-3＼cjkstart赤川砂州（11.0 11.6km）の横断図（1975年）

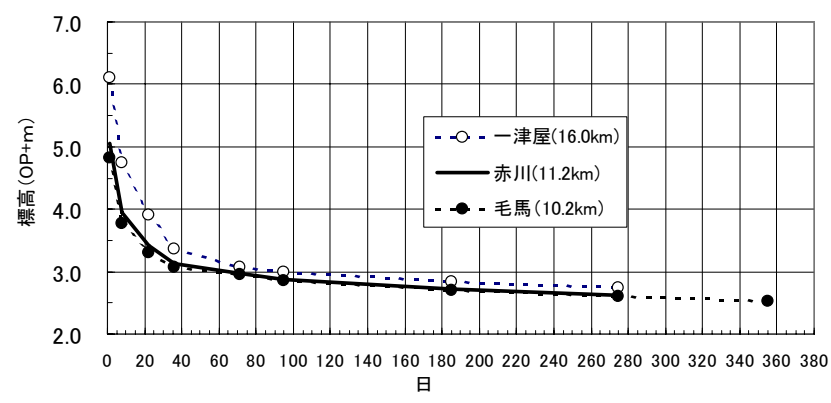

図-5 淀川下流の1970年代の位況図 : 毛馬量水標, 一津屋量水標，赤川地区 (11.2km) .
リが失われたばかりでなく，冠水帯や一時的水域も失 われ，赤川砂州の生態的機能が変質したこと，2）保全 された城北ワンド群でも冠水は希であり，洪水撹乱が ほとんど生じないことが分かる.

\section{3. 数值実験}

\section{(1) 目的}

イタセンパラの生息に必要な条件としてワンドやタ マリなどの水域の環境が時間的に変化し，止水性と流 水性の双方の性格が可能であることが考えられている7). すなわち平水時は止水性であるが，6～9月の雨季にお いては出水時に適切な流水環境が生じ，生活史の完結 および生息場の維持のためには流水による撹乱が必要 と考えられている．本研究では，A）地形の改変や水位 環境の変化により水域としては失われてしまったが, イタセンパラが生息していた1970年代初めの赤川ワン ド・タマリ群を対象として洪水時の水理環境の推定を 行い，その生息水域の水理学的特徵，特に必要とされ る洪水による撹乱の程度を知ること，および，B）水域 としては残されたが，近年イタセンパラが確認されて いない城北地区を対象として1970年代と劣化の著しい 2000年代と比較し，水理環境がどのように変化したの かを明らかにすることを数值実験の目的とした.

数值解析モデルとしてはJICEモデルを用い，流れの 平面二次元計算を行った。数值解析目的より1970年代,

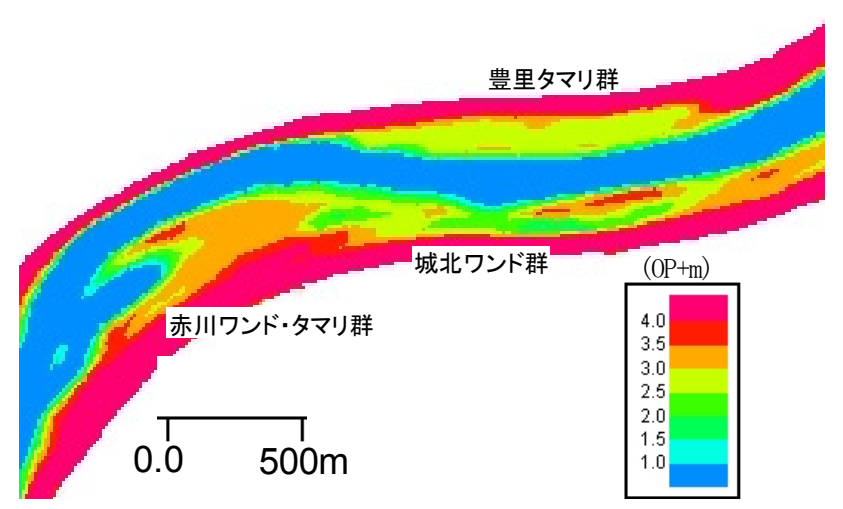

図-4＼cjkstart淀川下流の河床標高分布図 $(\mathrm{OP}+\mathrm{m})$

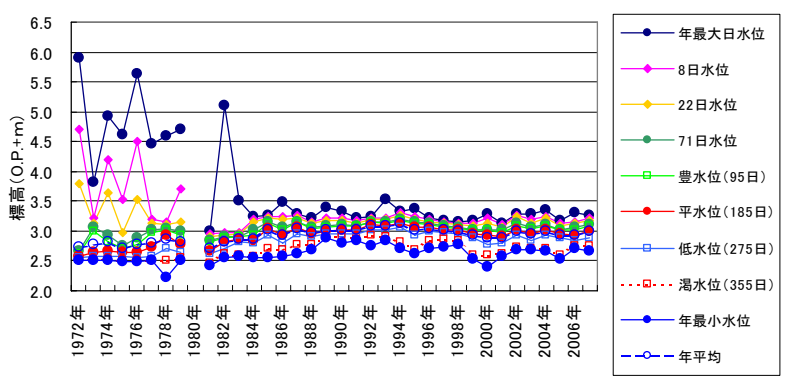

図-6 毛馬 (長柄) 水位観測所の位況の経年変化 
2000年代の地形モデルを用いた, 洪水流量が流れる時 の赤川地区，城北地区における水深，水位，流速の二 次元分布を求め, これらより擋乱の指標の一つとして 摩擦速度の分布と移動可能最大粒子径を求めた。

\section{(2) 実験条件}

地形モデルとして1971年横断測量のデータを用いて 作成された71年地形（9.2〜 17. $4 \mathrm{~km})$ ，および2005年測 量のデータから作成された 05 年地形（9.8〜 17. $4 \mathrm{~km} ）$ を

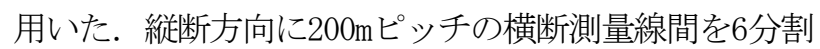
し，横断方向には堤外側の基点杭間を 25 分割すること により，計算メッシュを構成した。また，河床高は JICEモデルに内蔵された内挿法により作成した．従っ て, 解析領域内には城北や庭窪など現存するワンド群 も含まれるが，水制工やワンド床標高などの詳細な標 高分布は地形モデルに反映されていない.

上流端境界条件として流量を用い，流量值は枚方流 量観測所 $(26.0 \mathrm{~km})$ における観測資料を参考にして定 めた。 下流端境界としては71年地形では長柄可動堰地 点付近 $(9.2 \mathrm{~km}), 05$ 年地形では淀川大堰地点 （9. 8km）を下流端とし，各々でその当時の水位〜流量 曲線より得られる水位を与えた。 その他の計算条件と しては河床は固定床とし, 上流からの流砂の供給はな いものとした. 計算法としては上下流端の境界条件を 一定とし，非定常計算を長期間行うことにより，漸近 的な結果としての定常解を求めた.

\section{(3) 流量の設定と実験ケース}

行なった数值実験の条件を表-1にまとめて示した.

\section{a) Run Aシリーズ（赤川地区，城北地区）}

71年地形を用いた上流端流量 $1000 ， 2000 ， 4000 \mathrm{~m}^{3} / \mathrm{s}$ の場合の赤川地区を主対象とした実験である. 対象流 量 $4000 \mathrm{~m}^{3} / \mathrm{s}$ は枚方地点で10年に1回程度観測される流量

表-1 数値実験の条件のまとめ.

\begin{tabular}{|c|c|c|c|}
\hline Run No. & 地形モデル & 流量 $\left(\mathrm{m}^{3} / \mathrm{s}\right)$ & 下流端水位 $(0 \mathrm{P}+\mathrm{m})$ \\
\hline \hline $\mathrm{A} 1$ & 71 年 & 4000 & 6.166 \\
\hline $\mathrm{A} 2$ & 71 年 & 2000 & 5.055 \\
\hline $\mathrm{A} 3$ & 71 年 & 1000 & 4.000 \\
\hline $\mathrm{B} 1$ & 05年 & 4000 & 4.064 \\
\hline
\end{tabular}

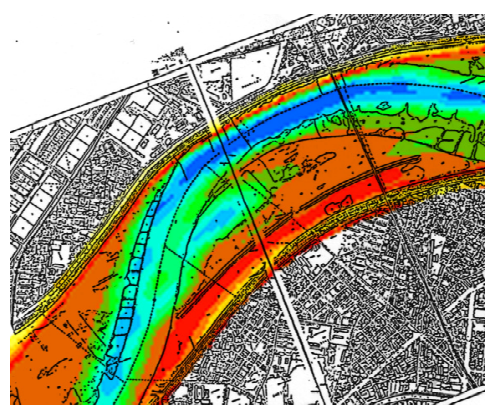

（a）赤川地区

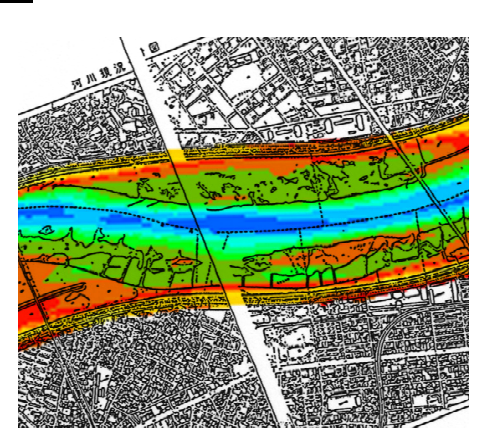

(b) 城北地区
であり， $2000 \mathrm{~m}^{3} / \mathrm{s}$ は毎年1回程度生起する，また 1000 $\mathrm{m}^{3} / \mathrm{s}$ は年5回程度生起する出水である. 下流端水位は水 位〜流量曲線より得られたものが表-1に記されている。 図-7（a）は71年地形モデルで作成された河床高分布を 赤川地区について示したものであり，赤川砂州の河床 高は0P+3.000〜4.000mと内挿されている.

b) RunBシリーズ（城北地区）

03年地形モデルを用いた，本川の流れが城北ワンド 群ワンドに冠水すると推定されている流量 $4000 \mathrm{~m}^{3} / \mathrm{s}$ の数 值実験である。下流端水位は淀川大堰地点の水位〜流 量曲線より得られた $0 \mathrm{P}+4.064 \mathrm{~m}$ である. 結果は71年地形 モデルを用いた $4000 \mathrm{~m}^{3} / \mathrm{s}$ (Run A1)， $2000 \mathrm{~m}^{3} / \mathrm{s}$ (Run A2) の数值計算結果から城北地区におけるものを抽出し, 1970年代と2000年代の環境の比較を行った.

図-7 (b) は71年地形により内挿された城北ワンド周 辺の河床高分布である. 城北ワンド群周辺の河床高は OP+2. 000〜3. 000m と内挿されている.

\section{4. 数值計算結果}

\section{(1) RunAシリーズ（赤川地区）}

71年地形モデルで流量 $1000 ， 2000 ， 4000 \mathrm{~m}^{3} / \mathrm{s}$ の計算 結果より，各々の流速分布を図-8（a）(b) (c) に，同様に 摩擦速度の分布を図-9 (a) (b) (c) に示した。流量1000 $\mathrm{m}^{3}$ /sで流れは両岸堤防際まで広がり砂州全体も冠水する。 以下では $2000 \mathrm{~m}^{3} / \mathrm{s}$ の場合を中心に述べる. 図-7(a)の河 床高分布図に見られるように，左岸側の砂州上と右岸 側澪筋にある淵とでは標高差が7m以上あり，水管橋と 鉄橋間の砂州の主要部で2000 $\mathrm{m}^{3} / \mathrm{s}$ 時には右岸側澪筋部 で8. 0 9. 0m, 砂州中央付近で2. 0 3. $0 \mathrm{~m}$, 左岸高水敷 付近で1. 0 2. $0 \mathrm{~m}$ 程度の水深が生じ，それに応じて流速 も各々 $1.00 \sim 1.40 \mathrm{~m} / \mathrm{s}, \quad 0.80 \sim 1.00 \mathrm{~m} / \mathrm{s}, \quad 0.60 \sim 0.80 \mathrm{~m} / \mathrm{s}$ 程度の流速が生じている. 摩擦速度は澪笳部で0. 080〜 $0.120 \mathrm{~m} / \mathrm{s}$, 砂州中央付近で $0.080 \sim 0.100 \mathrm{~m} / \mathrm{s}$, 左岸高水 敷で $0.020 \sim 0.080 \mathrm{~m} / \mathrm{s}$ の值となっている. 移動可能最大 砂粒子径 $d_{c}$ を岩垣式 程度, 高水敷上で $0.1 \sim 0.8 \mathrm{~cm}$ 程度以下の砂粒子が移動

図-7＼cjkstart赤川地区と城北地区の河床高分布（1971年） 

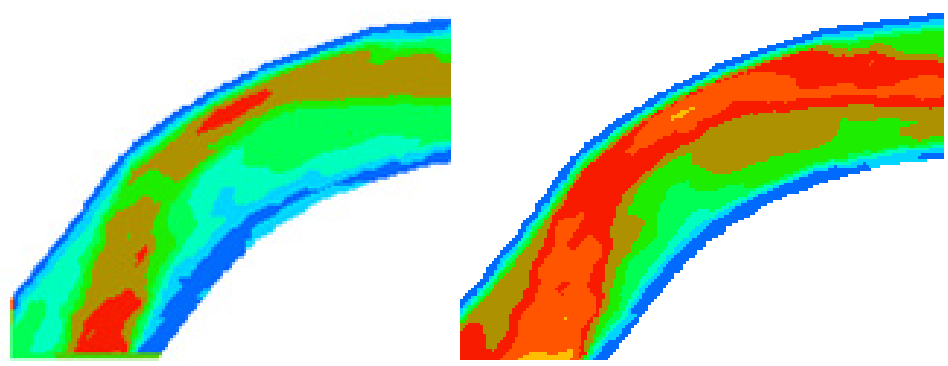

（a） 1971年地形，流量 $1000 \mathrm{~m}^{3} / \mathrm{s}$
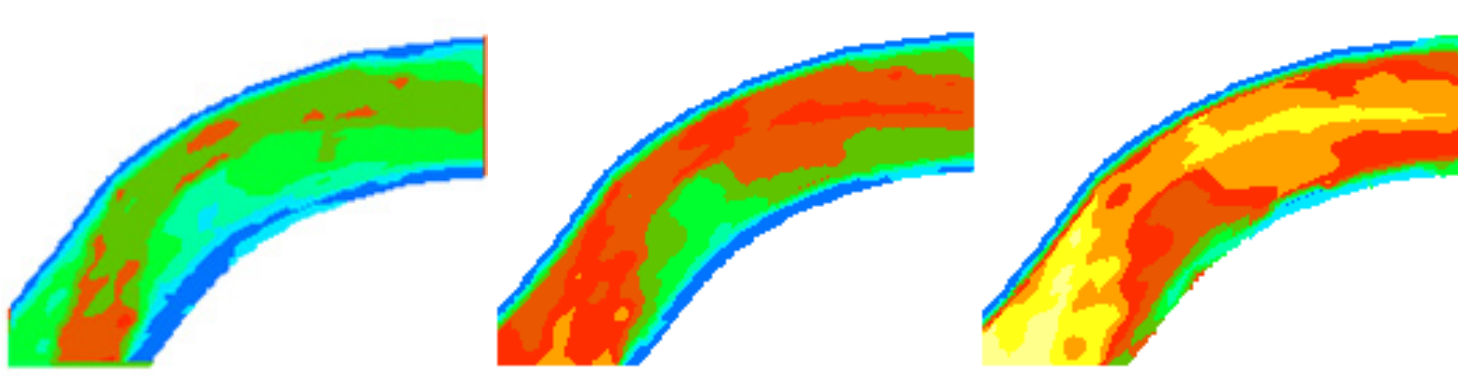

\begin{tabular}{|l|}
\hline$(\mathrm{m} / \mathrm{s})$ \\
\hline 0.160 \\
0.140 \\
0.120 \\
0.100 \\
0.080 \\
0.060 \\
0.040 \\
0.020 \\
0.000 \\
\hline
\end{tabular}

（a） 1971年地形，流量 $1000 \mathrm{~m}^{3} / \mathrm{s}$

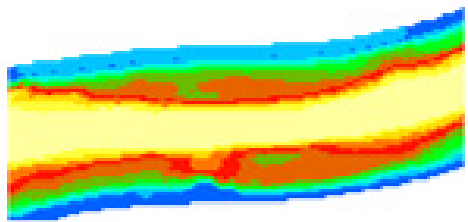

b) 1971 年地形，流量2000 $\mathrm{m}^{3} / \mathrm{s}$

（c） 1971年地形，流量 $4000 \mathrm{~m}^{3} / \mathrm{s}$

\begin{tabular}{|l|}
\hline \\
$(\mathrm{m} / \mathrm{s})$ \\
\hline 1.80 \\
1.60 \\
1.40 \\
1.20 \\
1.00 \\
0.80 \\
0.60 \\
0.40 \\
0.20 \\
0.00 \\
\hline
\end{tabular}

（c） 1971年地形，流量4000 $\mathrm{m}^{3} / \mathrm{s}$ 図-9＼cjkstart赤川地区における摩擦速度分布 $(\mathrm{m} / \mathrm{s})$.

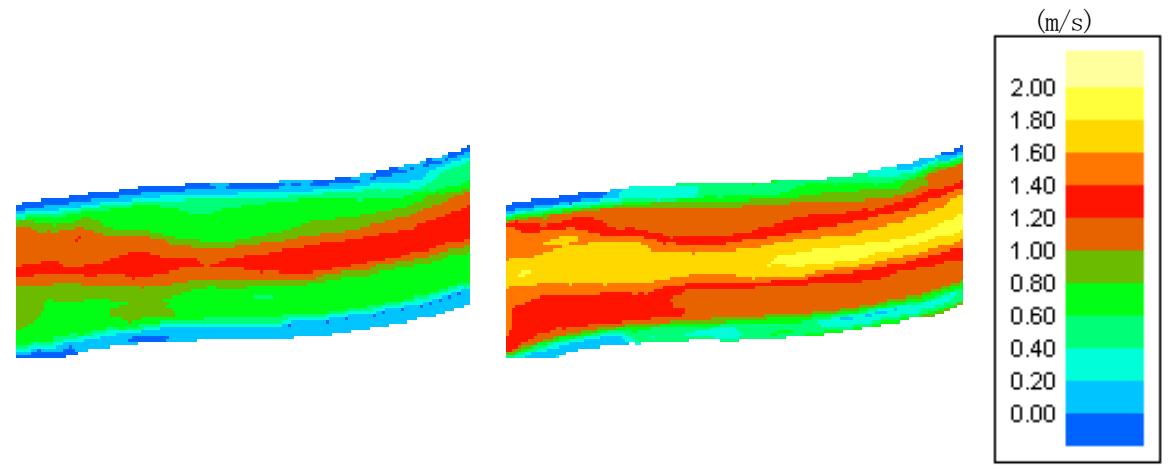

（a）2005年地形，流量 $4000 \mathrm{~m}^{3} / \mathrm{s}$

（b） 1971年地形，流量2000 $\mathrm{m}^{3} / \mathrm{s}$

（c） 1971年地形，流量4000 $\mathrm{m}^{3} / \mathrm{s}$

図-10 城北地区における流速分布 $(\mathrm{m} / \mathrm{s})$.

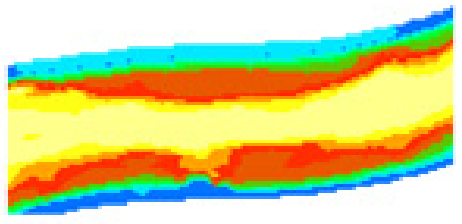

（a）2005年地形，流量4000 $\mathrm{m}^{3} / \mathrm{s}$

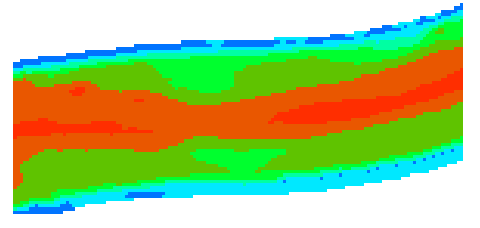

（b） 1971年地形，流量2000 $\mathrm{m}^{3} / \mathrm{s}$ 図-11 城北地区における摩擦速度分布 (m/s)

\begin{tabular}{|c|}
\multicolumn{1}{c|}{$(\mathrm{m} / \mathrm{s})$} \\
\hline 0.160 \\
0.140 \\
0.120 \\
0.100 \\
0.080 \\
0.060 \\
0.040 \\
0.020 \\
0.000
\end{tabular}

（c） 1971年地形, 流量4000 m³ $/ \mathrm{s}$ 
可能と概算された. 流量が $4000 \mathrm{~m}^{3} / \mathrm{s}$ の場合は砂州中央 部でも流速が $1.40 \sim 1.60 \mathrm{~m} / \mathrm{s}$, 摩擦速度が 0.120 $0.140 \mathrm{~m} / \mathrm{s}$ となり，2.0〜 $3.0 \mathrm{~cm}$ の粒径の砂粒子が移動す ることになる. 一方, 流量が $1000 \mathrm{~m}^{3} / \mathrm{s}$ の場合, 流速は 砂州主要部で $0.40 \sim 0.60 \mathrm{~m} / \mathrm{s}$, 摩擦速度は砂州主要部中 央で $0.040 \sim 0.060 \mathrm{~m} / \mathrm{s}$, 高水敷で $0.020 \sim 0.040 \mathrm{~m} / \mathrm{s}$ が生 じており, 主要部中央で粒径が $0.3 \sim 0.4 \mathrm{~cm}$ 程度, 高水 敷で $0.1 \sim 0.2 \mathrm{~cm}$ 程度の砂粒子が移動可能な洪水擋乱が 生じていることがわかった.

\section{(2) RunBシリーズ（城北地区）}

05年地形モデルで流量 $4000 \mathrm{~m}^{3} / \mathrm{s}$ ，および71年地形モ

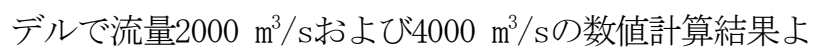
り，各々の流速分布を図-10 (a) (b) (c) に, 同様に摩擦 速度の分布を図-11 (a) (b) (c) に示した。05年地形モデ ルによる結果（図-10(a)，図-11(a)）では，河道改修 により澪筋部が掘削, 拡幅され複断面化したため低水 路部と高水敷の流れの違いが明瞭であって, 高水敷

（ワンド部）では流速 $0.80 \sim 1.40 \mathrm{~m} / \mathrm{s}$ ，摩擦速度 0.080 〜 $0.120 \mathrm{~m} / \mathrm{s}$ であり, 流速, 摩擦速度ともに低水路部に おけるものはこれより大きい. 現実には本計算モデル に含まれない高水敷部分の植生の存在により, 高水敷 部分の流速や摩擦速度はもつと小さいものと考えられ る.

71年地形モデルによる流量 $4000 \mathrm{~m}^{3} / \mathrm{s}$ の結果では澪筋 の流速や摩擦速度は05年モデルによるものより小さい が，高水敷（ワンド部）の流速や摩擦速度の大きさは それほど変わっていないことがわかる．71年地形モデ ル流量 $2000 \mathrm{~m}^{3} / \mathrm{s}$ の結果は, $4000 \mathrm{~m}^{3} / \mathrm{s}$ の場合と異なり, 高水敷（ワンド部）の流速は0. 60〜 $0.80 \mathrm{~m} / \mathrm{s}$ ，摩擦速度 は0. 020 0. 080m/s程度と小さくなっており, 赤川地区 の高水敷で得られたものと同程度である. なお，05年 地形モデルでは2000 $\mathrm{m}^{3} / \mathrm{s}$ の時, ワンドの冠水は生じず, 洪水撹乱は生じない.

以上のことより, 城北地区では河道改修後の現在で は冠水が生じる流量 $4000 \mathrm{~m}^{3} / \mathrm{s}$ 程度での高水敷の撹乱は 70年代と同程度のものが生じることがわかった。

\section{4. 結論}

本研究では，淀川水系におけるイタセンパラの生息 水域の再生を目標として, かつて同種の日本最大の生 息場であった本川下流水域の赤川砂州，および城北ワ ンド群を対象として, 同種の生活史上必要な生息水域 の洪水時の撹乱を明らかにすることを目的として，長 期間の水位観測記録の解析により生息水域の出水の大 きさと頻度の状況を明らかにした.さらに, 出水時の 流れの水理学的特性について, $4000 \mathrm{~m}^{3} / \mathrm{s}$ (再起期間 10 年程度），2000 m $3 / \mathrm{s}$ (年最大程度），1000 m $/ \mathrm{s}$ （年5 回程度）の洪水流量について二次元的な数值実験を行
い，流速分布および洪水撹乱の指標としての摩擦速度 の分布と移動可能最大砂粒子径について明らかにした. 水理学的特性について, 赤川地区ではイタセンパラが 生息していたワンド・タマリ群がある砂州主要部に, 城北地区ではワンドが存在する高水敷部分に着目し, 得られた結果をまとめると以下の様である.

\section{(1) RunAシリーズ（赤川地区）}

砂州主要部では流量が $1000 \mathrm{~m}^{3} / \mathrm{s}$ の時，流速は0.40〜 $0.60 \mathrm{~m} / \mathrm{s}$ ，摩擦速度が $0.040 \sim 0.060 \mathrm{~m} / \mathrm{s}$ ，移動可能最大 砂粒子径は0. 3〜0. $4 \mathrm{~cm}$ と計算された. このことから 1970年代の赤川砂州主要部のワンド・タマリ群では年 間に5回程度の洪水撹乱が行われていたことが推定され る.

\section{(2) RunBシリーズ（城北地区）}

城北地区の高水敷（ワンド部）では71年地形，05年 地形ともに流量 $4000 \mathrm{~m}^{3} / \mathrm{s}$ の時, 流速は0. 80〜 $1.40 \mathrm{~m} / \mathrm{s}$, 摩擦速度 $0.080 \sim 0.120 \mathrm{~m} / \mathrm{s}$, 移動可能最大砂粒子径は 0.6〜2. $0 \mathrm{~cm}$ と同程度の結果が得られた. 71 年地形モデ ル流量 $2000 \mathrm{~m}^{3} / \mathrm{s}$ の時, 流速 $0.60 \sim 0.80 \mathrm{~m} / \mathrm{s}$, 摩擦速度 $0.020 \sim 0.080 \mathrm{~m} / \mathrm{s}$ 程度であり，赤川地区の高水敷（ワン ド部）と同程度の結果が得られた。また，05年地形で は年最大流量 $2000 \mathrm{~m}^{3} / \mathrm{s}$ 程度以下の規模の洪水では冠水 は生じず，撹乱は失われた。

謝辞 : 本文の執筆に当たり，ご助言頂いた紀平肇先生， 河合典彦先生に深く感謝申し上げます。快く資料の提 供を頂いた国土交通省淀川河川事務所，淀川資料館， 河川環境管理財団近畿事務所の皆様に謝意を表します.

\section{参考文献}

1)綾史郎，辻本哲郎，芦田和男 : ワンドの機能と保全·創造, 河川環境管理財団大阪研究所, 平成11年3月.

2) 片野修 : ナマズはどこで卵を生むのか，川魚たちの自然史， 創樹社, 1998.

3) 河川環境管理財団編 : 流水, 土砂の管理と河川環境の保全 と復元に関する研究（改訂版），平成17年11月.

4) 紀平肇, 長田芳和 : 魚類および貝類, 淀川河川敷生態調査 報告書, 淀川工事事務所, pp202-251, 1974.

5) 長田芳和，紀平肇，鉄川精 : 無機環境，淀川河川敷生態調 查報告書, 淀川工事事務所, pp22-37, 1975.

6) 綾史郎, 有馬忠雄, 紀平肇, 井田康夫 : 淀川における位況 と冠水域, 水工学論文集, vol45, pp1117-1122, 2001.

7) 小川力也, 長田芳和 : 河川汇濫原のシンボルフィッシューイ タセンパラ, 森誠一編著, 自然復元特集 5 , 淡水生物の保全 生態学, 信山社サイテック, pp9-18, 1999.

8) 土木学会水理委員会水理公式集改訂小委員会編 : 水理公式 集, 土木学会, $\mathrm{p} 158$, 平成11年.

(2010.9. 30受付) 